\title{
Anatomic Versus Non-Anatomic Hepatic Resection for Patients with Stage I and II Hepatocellular Carcinoma
}

\author{
Abdelhady H, MD; Hosssam I, MD; Ismaeil T, MD; El-sheikh M, MD; \\ Abdelwahab M, MD; Soliman M, MD; Hassan O, MD.
}

\author{
Department of General Surgery, Tanta University, Tanta, Egypt.
}

\begin{abstract}
Aim: This retrospective study compares the outcome of patients undergoing anatomical versus non-anatomical hepatic resection for stage I and II HCC.

Patients and methods: This retrospective study included 25 patients with T I and II HCC managed by hepatic resection. Patients were divided into two groups. Group A: Anatomic resection (n: 14) was treated by the complete removal of at least one liver segment. Group B: Non-anatomic resection (n:11) was treated by the resection of the tumor with a margin of at least $1 \mathrm{~cm}$ without regard to segmental, sectional or lobar anatomy. The two patients groups were subjected to a close follow-up of $23.9 \pm 8.22$ months.

Results: No difference was detected between the 2 groups in clinical and demographic characteristics. Mean operative time was $3.11 \pm 1.00$ versus $3.18 \pm 0.717$ hours (p: 0.84). Mean operative blood loss was $1050 \pm 626$ versus $1045 \pm 460$ (p: 0.27). Mean tumor size was $4.00 \pm$ $0.855 \mathrm{~cm}$ and $3.73 \pm 1.06 \mathrm{~cm}$ (p: 0.48). Tumors were capsulated in $10(71.4 \%)$ group A and 8 (72.7\%) Group B patients. Resection margin was infiltrated in 2 (14.3\%) and 1 (9.1\%) patients. Microscopic invasion was found in $5(35.7 \%)$ and 4 (36.4\%) patients. Mean period of hospital stay was $8.29 \pm 7.04$ and $6.45 \pm 3.05$ days (p: 0.43). There were early complications in 8 patients (57.1\%) from group $A$ and 3 patients (21.3\%) from Group B (p: 0.15). Severe deterioration in liver functions and eventually death occurred in 1 patient and postoperative hemorrhagic shock and ARDS leading to death in 1 patient. During early follow up, 8 patients (57.1\%) from group A and 8 patients (72.7\%) from Group B developed recurrence; 3 patients (21.3\%) and 4 patients (36.4\%) within 1 year after operation. Mean time of recurrence was $14.0 \pm 6.14$ versus $12.1 \pm 8.11$ months ( $p: 0.61$ ). Using the univariate analysis method, there was no difference between the 2 groups in recurrence (p: 0.44). Six patients (42.8\%) from group A and 3 patients (27.3\%) from group B died during the follow up period. Mean diseasefree survival was $15.071 \pm 2.298$ versus $15.182 \pm 2.652$ months (p: 0.98). Cumulative overall survival proportion was $58.2 \%$ versus $72.7 \%$. Mean overall survival was $18.214 \pm 2.361$ months versus $21.909 \pm 1.156$ (p: 0.21). Results of univariate analysis showed no statistically significant factors to differentiate between both groups.

Conclusion: We conducted this retrospective analysis for patients with HCC undergoing hepatic resection, and examined the background and clinical outcomes. The local recurrence rate was similar after anatomical and non-anatomical resection. Disease-free and overall survivals after anatomical and non-anatomical resection were not significantly different. Hepatic resection in cirrhotic patients should be done with good expertise and follows strict selection criteria. Non-Anatomical resection may be more preferable in cirrhotic patients with small HCC to leave adequate functioning liver parenchyma and to avoid increased postoperative morbidity.
\end{abstract}

\section{Introduction:}

Hepatocellular Carcinoma (HCC) is the fifth most frequent cancer in the world and the third most common cause of cancer 
mortality. ${ }^{1}$ Although more common in Asia and Africa, the incidence of HCC is increasing in the Western world. ${ }^{2}$

Resection for HCC is a widely accepted safe treatment with a very low operative mortality as a result of advances in surgical techniques and peri-operative management. ${ }^{3}$ However, identifying an optimum extent of resection is often difficult due to underlying liver disease such as chronic hepatitis or cirrhosis in most patients. ${ }^{4}$ Based on the fact that cirrhotic liver has limited capacity to regenerate, 5 many surgeons perform limited resection for $\mathrm{HCC}$, focusing on the preservation of $1 \mathrm{~cm}$ or greater tumorfree margin to reduce postoperative liver failure in patients with cirrhosis. ${ }^{6}$ Anatomic liver resection is theoretically superior to non-anatomic from the oncologic and anatomic aspects, ${ }^{7}$ however, this technique is considered technically more demanding and often requires a wider extent of parenchymal sacrifice. ${ }^{3,8}$ Additionally, several clinical studies have failed to document any improvement in survival. ${ }^{9-11}$

The rate of development of postoperative recurrence after hepatic resection remains high. ${ }^{12}$ Early recurrence within 2 years of hepatic resection for HCC is likely to be associated with aggressive tumor biology such as high tumor grade, satellite lesions and microvascular invasion. ${ }^{13}$

This retrospective study compares the outcome of patients undergoing anatomical versus non-anatomical hepatic resection for stage I and II HCC. This included postoperative morbidity, recurrence of malignancy and overall survival rates.

\section{Patients and methods:}

This retrospective study included 25 patients with stage I and II HCC managed by hepatic resection at Gastroentrology Surgery Center, Mansora University and Gastro- intestinal and laparoscopic surgery unit, General Surgery Department, Tanta University Hospital during the period from January 2008 to June 2010. Date of last follow up was the end of December 2011.

Patients with extra-hepatic metastasis, diffuse HCC involving more than two adjacent segments or two non-adjacent segments, main portal vein thrombosis or main hepatic vein or IVC invasion or impaired liver functions (late B and C Child-Pugh classification) were excluded from this study.

\section{Patient characteristics:}

The following clinical variables were compared in the two groups: age, sex, viral markers, presence or absence of cirrhosis, serum albumin, serum total bilirubin, Child-Pugh classification and serum AlphaFetoprotein (AFP).

\section{Hepatectomy procedures:}

The patients were divided into two groups. Group A: Anatomic resection (n: 14) was defined as the complete removal of at least 1 Couinaud's segment containing the tumor together with the related portal vein and the corresponding hepatic territory. The appropriate segment margins were identified by intra-operative US after discoloration of the parenchyma after ligation of the corresponding arterial and portal venous branches or both. Group B: Non-anatomic resection (n: 11) was defined as the resection of the tumor with a margin of at least $1 \mathrm{~cm}$ without regard to segmental, sectional or lobar anatomy.

Patient follow-up:

The two patients groups were subjected to a close follow-up of $23.9 \pm 8.22$ months. During this period they underwent clinical, radiologic (abdominal ultrasound and triphasic abdominal CT scan) and biologic (serum AFP and liver function tests) evaluations. This assessment was repeated every 3 months throughout the follow-up period.

\section{Statistical analysis:}

Quantitative variables were expressed as mean \pm SD. Qualitative variables were expressed as frequency and percent. Quantitative parametric variables were compared between the two groups using the unpaired student t-test, quantitative 
non-parametric variables were compared using Mann-Whitney test. Qualitative variables were compared using Chi-square test or Fisher exact test when the criteria for using Chi-square were not sufficient log-rank tests and Cox's proportional hazards model were used to identify factors influencing long-term survival. Survival was calculated using the Kaplan-Meier method. The power used was 0.80 while the level of significance was $5 \%$.

\section{Results:}

No difference was detected between the 2 groups in terms of clinical and demographic characteristics with respect to age, sex, viral hepatitis markers, the presence of underlying liver cirrhosis, Child-Pugh scoring and AFP levels Table (1).

Left Hepatectomy was done in 1 case, 7 cases with left lateral and other segmental resection was done in 6 cases. Non-anatomical resection was done in 11 cases Table (2).

One patient of Group B had hemorrhage due to injury of caudate lobe (segment I) vein to Inferior Vena Cava during localized resection of segment (VI) tumor and it was controlled by suturing with Ethibond 3/0. The mean operative time was $3.11 \pm 1.00$ versus $3.18 \pm 0.717$ hours (p: 0.84 ). The mean operative blood loss during surgery was $1050 \pm 626$ versus $10545 \pm 1460$ (p: 0.27). Table (3).

Tumor size ranged from 2 to $5 \mathrm{~cm}$ with a mean size of $4.00 \pm 0.855 \mathrm{~cm}$ and 3.73 $\pm 1.06 \mathrm{~cm}$ respectively (p:0.48). Tumors were capsulated in $10(71.4 \%)$ group A and $8(72.7 \%)$ Group B patients. Resection margin was infiltrated in $2(14.3 \%)$ group $\mathrm{A}$ and 1 (9.1\%) Group B patients. Trans Arterial Chemo Embolization (TACE) was done postoperatively in 2 patients while one patient died after 1 month from acute liver cell failure before doing TACE. Microscopic invasion was found in 5 (35.7\%) group $A$ and 4 (36.4\%) Group B patients. Table 4 details the histo-pathological data of both groups.

Tumors were mostly well differentiated pure HCC in most of the patients. One patient had Fibrolamellar HCC and another one had mixed HCC and Cholagiocarcinoma Table (5).

The mean period of hospital stay was $8.29 \pm 7.04$ days in group A and $6.45 \pm 3.05$ days in Group B (p: 0.43). There were early complications in 8 patients $(57.1 \%)$ from group A and 3 patients (21.3\%) from Group B (p: 0.15). The most frequent complication was subphrenic collection, ultrasonography guided aspiration was done, while in one case medical treatment and follow up were enough. Pleural effusion was treated medically, while chest tube was inserted in one case with bilateral effusion. Biliary leakage was minor leakage. It was treated conservatively within 10 days. Severe deterioration in liver functions and eventually death occurred in 1 patient and postoperative hemorrhagic shock and adult respiratory distress syndrome (ARDS) leading to death in 1 patient. During follow up, 2 patients were noted to have incisional hernia.

\section{Recurrence:}

During the follow up period 8 patients (57.1\%) from group A and 8 patients (72.7\%) from Group B developed recurrence; 3 patients $(21.3 \%)$ from group $\mathrm{A}$ and 4 patients (36.4\%) from Group B occurred early within 1 year after operation, while the rest showed the recurrence after 1 year. Mean time of recurrence was $14.0 \pm 6.14$ versus $12.1 \pm 8.11$ months (p: 0.61). Two patients from each groups developed distant (extrahepatic) metastases (including brain, lung and supraclavicular lymph node metastasis). TACE, Percutaneous RadioFrequency Ablation (RFA) or supportive medical treatment (medical liver support and pain killers) were given according to general conditions and liver functions.

Using the univariate analysis method, there was no difference between the 2 groups in terms of recurrence through the follow-up period (p: 0.44).

\section{Mortality:}

Six patients $(42.8 \%)$ from group A and 3 patients (27.3\%) patients died during the follow up period. Two of them died 
during hospital stay; case $1: 10$ days due to postoperative hemorrhagic shock and ARDS, and case 2: 14 days due to Acute Liver Cell Failure (LCF). There was no intraoperative mortality Table (7).

Overall and disease free survival rates:

The mean disease-free survival was $15.071 \pm 2.298$ versus $15.182 \pm 2.652$ months (p: 0.98). The cumulative overall survival proportion at end of research was $58.2 \%$ versus $72.7 \%$. The mean overall survival was $18.214 \pm 2.361$ months versus 21.909 \pm 1.156 (p: 0.21). Figure 1 compares the disease-free survival and Figure 2 compares the cumulative overall survival between both groups.

Factors affecting overall survival:

The results of univariate analysis using Kaplan-Meier method for relation between different epidemiological, clinical and pathological variables and Overall Survival (OAS) are showed in Table (8). There were no statistically significant factors to differentiate between both groups.

\section{Discussion:}

HCC has recently gained major clinical interest because of its increasing incidence worldwide and the potential to diagnose and treat the disease at an early stage. ${ }^{14-16}$ Although liver transplantation has proven to be an alternative option for the surgical management of $\mathrm{HCC}$ in cirrhotic patients, its use is limited by the shortage of donors. ${ }^{17}$ Hepatic resection remains the treatment of choice offering the possibility of cure, but the long-term prognosis remains unsatisfactory due to the high recurrence rate. ${ }^{18-20}$ Early recurrence is considered one of the most important factors that impact the prognosis of HCC patients. ${ }^{21}$

The present study attempts to determine the impact of the type of liver resection (anatomical versus non-anatomical) in a group of patients with solitary HCC. The patients were similar in preoperative clinical characteristics and tumor biology. The study showed through close follow-up of 23.9 \pm 8.22 months that the type of resection is not considered a risk factor for early tumor recurrence.

The prognosis of recurrent HCC after resection depends on the time of recurrence, supporting the hypothesis that recurrent tumors are subclinical metastases, originating from the primary tumor and missed during treatment (early recurrence), or de novo HCC arising from persistent fibrosis and hepatitis related carcinogenicity in the remnant liver (late recurrence). ${ }^{22-26}$ In these studies, early recurrence was associated with adverse tumor factors, especially vascular invasion, whereas late recurrence was reported to be primarily associated with the presence of cirrhosis. From these studies, only one study by Imamura et al. ${ }^{23}$ included the type of resection as a possible risk factor for early recurrence. They concluded that nonanatomic resection is considered a risk factor for early recurrence. However, in this study non-anatomic resection was classified into tumor enucleation and limited resection. The resection margin was not identified in the resection group.

In our study all patients undergoing non-anatomic resection had a $1 \mathrm{~cm}$ clear margin. A recent study by Cucchetti et $\mathrm{al}^{25}$ compared different risk factors for early and late recurrence in cirrhotic HCC patients. They concluded that the type of resection (anatomical versus non-anatomical) is not considered a risk factor for early tumor recurrence which coincides with the results of our study.

While some authors have found anatomic resection to have a beneficial effect on recurrence-free survival for $\mathrm{HCC},{ }^{26}$ others have found that anatomic and non-anatomic resection had no significant impact on the risk of tumor recurrence. $8,31,32$ These studies were based on overall long-term survival and therefore early and late recurrence risk factors were not taken into consideration.

Some European and Asian institutes have previously reported the survival benefit of anatomical or systematic hepatic resection such as segmentectomy in HCC patients. ${ }^{27-33}$ From an oncological point of view, 

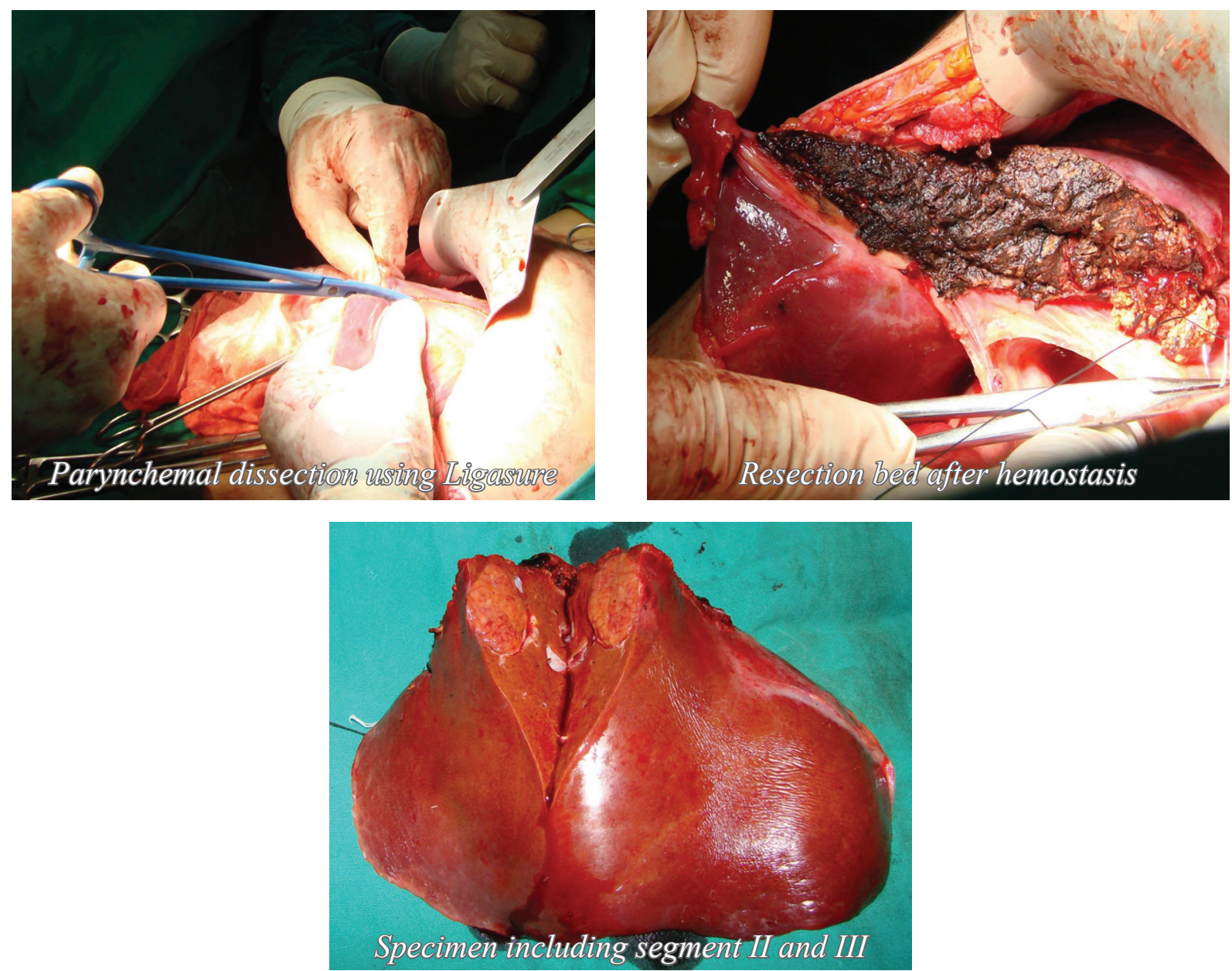

Figure (1): Case 1: Group A; Anatomical resection; Left lateral segmentectomy.
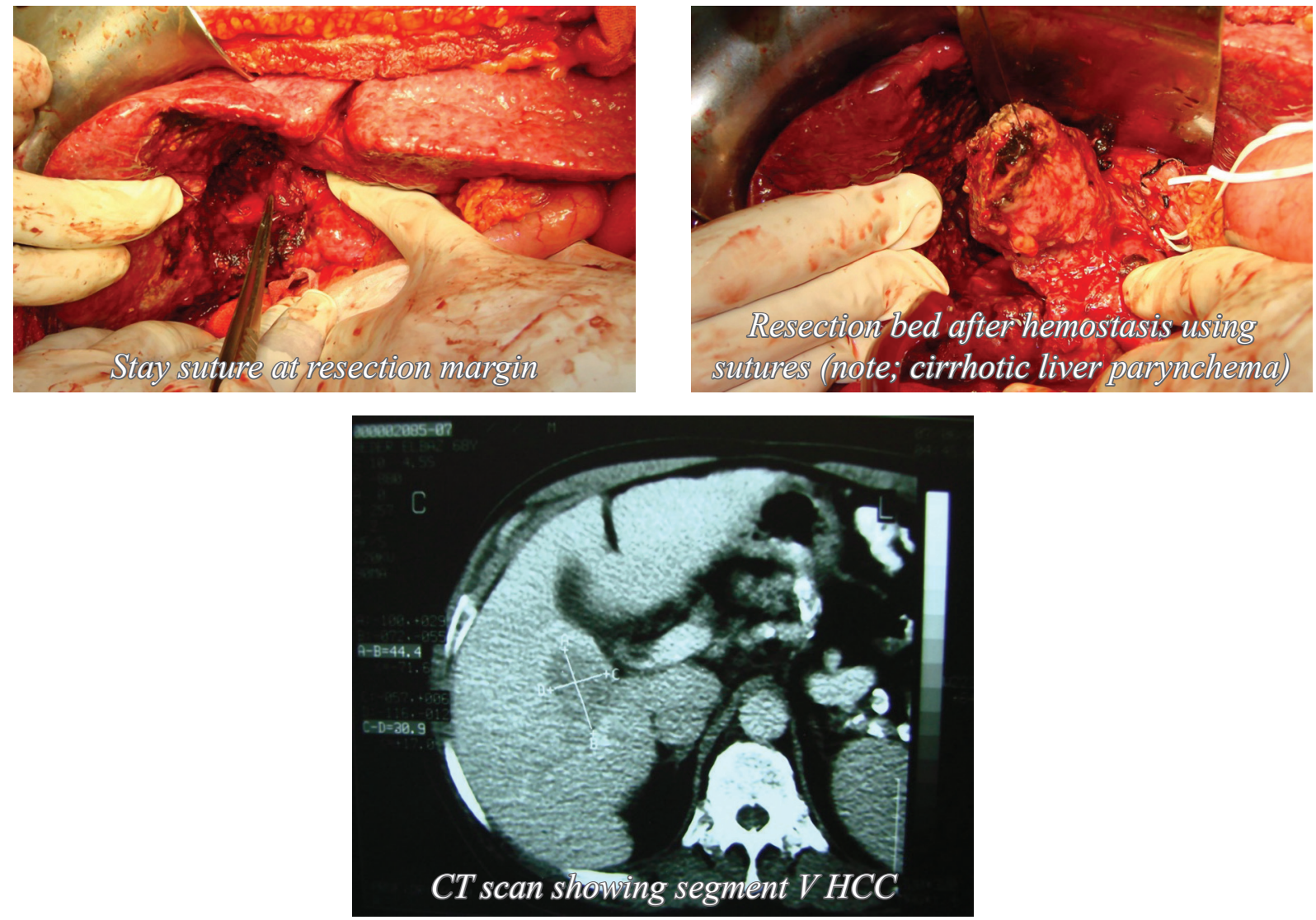

Figure (2): Case 2: Group B; Non-Anatomical resection; localized segment V resection. 


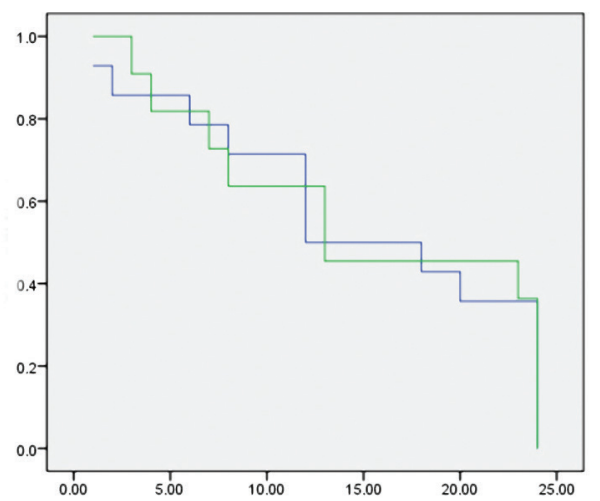

Figure (3): Kaplan-Meier curve compares the disease-free survival between both groups (line 1: Anatomical Resection group, Line 2: Non-Anatomical Resection group).

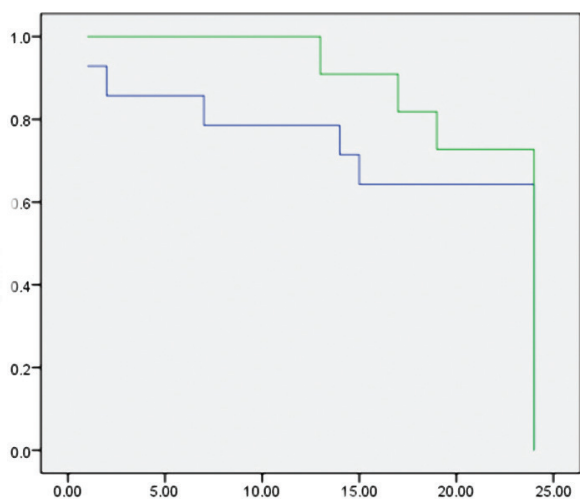

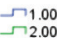

Table (1): Pre-operative demographic data.

\begin{tabular}{|l|l|l|l|}
\hline \multicolumn{1}{|c|}{ Variable } & \multicolumn{1}{|c|}{$\begin{array}{c}\text { Anatomical } \\
\text { Resection group }\end{array}$} & $\begin{array}{c}\text { Non-Anatomical } \\
\text { Resection group }\end{array}$ & \multicolumn{1}{c|}{$\mathbf{p}$} \\
\hline Age (years) & $51.0 \pm 10.1$ & $57.1 \pm 4.55$ & 0.077 \\
\hline Sex (M/F) & $10 / 4$ & $8 / 3$ & 0.16 \\
\hline HBV (yes/no) & $4 / 10$ & $3 / 8$ & 0.94 \\
\hline HCV (yes/no) & $8 / 6$ & $5 / 6$ & 0.89 \\
\hline Cirrhosis (yes/no) & $10 / 4$ & $9 / 2$ & 0.57 \\
\hline Child-Pugh (A/B) & $12 / 2$ & $9 / 2$ & 0.17 \\
\hline AFP level (ng/mL) & $107 \pm 153$ & $142 \pm 189$ & 0.61 \\
\hline
\end{tabular}

HBV: Hepatitis B virus; HCV: Hepatitis C virus; AFP: Alpha-Fetoprotein

Table (2): Types of hepatic resection in the studied groups.

\begin{tabular}{|l|l|l|l|l|}
\hline & Anatomical Resection group & & Non-Anatomical Resection group & \\
\hline No. & 14 & & 11 & \\
\hline \multirow{4}{*}{ Type } & Left Hepatectomy & 1 & II & 1 \\
\cline { 2 - 5 } & Left lateral Hepatectomy & 7 & III & 2 \\
\cline { 2 - 5 } & Segmental : & 6 & V & 1 \\
\cline { 3 - 5 } & \multirow{2}{*}{ I, IVb, V, VI, VII } & & VI & 4 \\
\cline { 3 - 5 } & & & VII & 2 \\
\cline { 3 - 5 } & & & VIII & 1 \\
\hline
\end{tabular}

anatomical hepatic resection may be ideal, because cancer cells are thought to spread along locoregional Glisson's vessels in the same segment as other intrahepatic lesions. ${ }^{34}$ Regimbeau et al. ${ }^{31}$ reported shorter tumorfree and overall survival rates and a higher local recurrence rate in HCC patients who underwent limited resection compared to
Figure (4): Kaplan-Meier curve compares the cumulative overall survival between both groups (line 1: Anatomical Resection group, Line 2: Non-Anatomical Resection group). 
Table (3): Comparison of operative data between both groups.

\begin{tabular}{|l|l|l|l|}
\hline & \multicolumn{1}{|c|}{$\begin{array}{c}\text { Anatomical } \\
\text { Resection group }\end{array}$} & $\begin{array}{c}\text { Non-Anatomical } \\
\text { Resection group }\end{array}$ & \multicolumn{1}{|c|}{ p } \\
\hline Operative complications & 0 & 1 (hemorrhage) & \\
\hline Operative time & $2-5.5$ hours & $2.5-5$ hours & 0.84 \\
Mean & $3.11 \pm 1.00$ & $3.18 \pm 0.717$ & \\
\hline Blood loss $(\mathrm{ml})$ & $250-2000$ & $500-5000$ & 0.27 \\
Mean & $1050 \pm 626$ & $10545 \pm 1460$ & \\
\hline
\end{tabular}

Table (4): Details and comparison of histo-pathological data between both groups

\begin{tabular}{|c|c|c|c|c|}
\hline & & $\begin{array}{c}\text { Anatomical } \\
\text { Resection } \\
\text { group }\end{array}$ & $\begin{array}{l}\text { Non-Anatomical } \\
\text { Resection group }\end{array}$ & $\mathbf{p}$ \\
\hline Liver & $\begin{array}{l}\text { Cirrhotic } \\
\text { Noncirrhotic }\end{array}$ & $\begin{array}{l}10(71.4 \%) \\
4(28.6 \%) \\
\end{array}$ & \begin{tabular}{|l|}
$9(81.8 \%)$ \\
$2(18.2 \%)$ \\
\end{tabular} & 0.57 \\
\hline Mean Tumor size $(\mathrm{cm})$ & & $4.00 \pm 0.855$ & $3.73 \pm 1.06$ & 0.48 \\
\hline Tumor capsule & $\begin{array}{l}\text { Yes } \\
\text { No }\end{array}$ & $\begin{array}{l}10(71.4 \%) \\
4(28.6 \%)\end{array}$ & $\begin{array}{l}8(72.7 \%) \\
3(27.3 \%) \\
\end{array}$ & 0.95 \\
\hline Resection margin & $\begin{array}{l}\text { Free } \\
\text { Infiltrated }\end{array}$ & $\begin{array}{l}12(85.7 \%) \\
2(14.3 \%) \\
\end{array}$ & $\begin{array}{cc}10 & (90.9 \%) \\
1 & (9.1 \%) \\
\end{array}$ & 0.71 \\
\hline Microscopic invasion & $\begin{array}{l}\text { Yes } \\
\text { No }\end{array}$ & $\begin{array}{l}5(35.7 \%) \\
9(64.3 \%) \\
\end{array}$ & $\begin{array}{l}4(36.4 \%) \\
7(63.6 \%)\end{array}$ & 0.97 \\
\hline
\end{tabular}

Table (5): Pathological types and differentiation of tumors in the studied groups

\begin{tabular}{|c|l|l|}
\hline & \multicolumn{1}{|c|}{$\begin{array}{c}\text { Anatomical } \\
\text { Resection group }\end{array}$} & $\begin{array}{c}\text { Non-Anatomical } \\
\text { Resection group }\end{array}$ \\
\hline HCC : & $13(92.8 \%)$ & $10(90.9 \%)$ \\
\hline Well Differentiated (Grade I) & $6(42.8 \%)$ & $4(36.4 \%)$ \\
\hline Moderately Differentiated (Grade II) & $4(28.6 \%)$ & $3(27.3 \%)$ \\
\hline Poorly Differentiated (Grade III) & $3(21.3 \%)$ & $3(27.3 \%)$ \\
\hline Fibrolamellar HCC & $1(7.1 \%)$ & - \\
\hline Mixed HCC-CC* & - & $1(9.1 \%)$ \\
\hline
\end{tabular}

*Mixed HCC-Cholagiocarcinoma

cirrhotic patients with severely impaired liver function. ${ }^{35}$ No randomized controlled study between anatomical and non-anatomical resection $^{36}$ for $\mathrm{HCC}$ under the same situation concerning tumor factor and liver function has been reported.

Nanashimaetal, ${ }^{37}$ conductedaretrospective analysis of prognosis in 113 Japanese HCC patients who underwent hepatic resection, and examined the background and clinical outcomes. In the non-anatomical resection group, a smaller size of tumor and impaired liver function were significantly frequent; however, the local recurrence rate was similar between the non-anatomical resection and anatomical resection groups. Diseasefree and over- all survival in the anatomical resection and non-anatomical resection groups with a negative surgical margin were not significantly different despite the degree of liver dysfunction and the surgical margin was not related to the outcome. Survival in 
Table 6: Postoperative data of both studied groups

\begin{tabular}{|c|c|c|c|}
\hline & $\begin{array}{c}\text { Anatomical Resection } \\
\text { group }\end{array}$ & $\begin{array}{c}\text { Non-Anatomical Resection } \\
\text { group }\end{array}$ & $\mathbf{p}$ \\
\hline $\begin{array}{l}\text { Hospital stay (days) } \\
\text { Mean }\end{array}$ & \begin{tabular}{|l|}
$4-32$ \\
$8.29 \pm 7.04$
\end{tabular} & $\begin{array}{l}3-13 \\
6.45 \pm 3.05\end{array}$ & 0.43 \\
\hline $\begin{array}{l}\text { Postoperative } \\
\text { complications }\end{array}$ & $\begin{array}{l}8 \text { patients (57.1\%) : } \\
\text { Bile leakage } 1 \\
\text { Collection } \quad 4 \\
\text { Effusion } \quad 3\end{array}$ & $\begin{array}{ll}3 \text { patients }(21.3 \%): & \\
\text { Hemorrhage, ARDS } & 1 \\
\text { Collection } & 1 \\
\text { Effusion } & 1\end{array}$ & 0.15 \\
\hline Late complications & $\begin{array}{ll}\text { LCF } & 1 \\
\text { Incisional hernia } 1\end{array}$ & - & \\
\hline
\end{tabular}

Table 7: Recurrence and mortality comparison between both groups

\begin{tabular}{|l|l|l|l|}
\hline & $\begin{array}{c}\text { Anatomical } \\
\text { Resection group }\end{array}$ & \multicolumn{1}{|c|}{$\begin{array}{c}\text { Non-Anatomical } \\
\text { Resection group }\end{array}$} & \multicolumn{1}{|c|}{ p } \\
\hline Recurrence: & $8(57.1 \%):$ & $8(72.7 \%):$ & 0.44 \\
\hline Recurrence within 1 year & $3(21.3 \%)$ & $4(36.4 \%)$ & \\
\hline Recurrence after 1 year & $5(35.8 \%)$ & $4(36.4 \%)$ & \\
\hline Mean time of recurrence(months) & $14.0 \pm 6.14$ & $12.1 \pm 8.11$ & 0.61 \\
\hline Mortality & $6(42.8 \%)$ & $3(27.3 \%)$ & 0.43 \\
\hline
\end{tabular}

Table 8: Univariate analysis of factors affecting Overall Survival

\begin{tabular}{|l|l|l|l|l|}
\hline & & $\begin{array}{l}\text { Anatomical } \\
\text { Resection group: } \\
\text { Mean Survival } \\
\text { (months) }\end{array}$ & $\begin{array}{l}\text { Non-Anatomical } \\
\text { Resection group: } \\
\text { Mean Survival } \\
\text { (months) }\end{array}$ & p value \\
\hline Age & $\begin{array}{l}\leq 60 \text { years } \\
>60 \text { years \# }\end{array}$ & $\begin{array}{l}19.2 \pm 7.8 \\
16.3\end{array}$ & $\begin{array}{l}23.2 \pm 2.04 \\
20.45 .13\end{array}$ & 0.24 \\
\hline Sex & Male & $18.6 \pm 8.71$ & $22.8 \pm 2.57$ & 0.16 \\
& Female & $21.8 \pm 4.50$ & $20.3 \pm 6.35$ & 0.74 \\
\hline Child & A & $19.9 \pm 7.97$ & $20.1 \pm 6.35$ & 0.95 \\
Classification & B \# & 13 & 21.5 & 0.22 \\
\hline Liver Cirrhosis & Cirrhotic & $16.9 \pm 9.88$ & $21.4 \pm 4.13$ & $18.3 \pm 9.81$ \\
\hline Capsule & Non-Cirrhotic & $22.0 \pm 4.47$ & $18.8 \pm 5.92$ & 0.92 \\
& No & $19.1 \pm 8.39$ & $22.0 \pm 2.00$ & 0.40 \\
\hline Resection Margin & Yes & $16.0 \pm 10.9$ & $21.7 \pm 3.97$ & 0.42 \\
& Infiltrated \# & $19 . \pm 57.61$ & 7 & 0.95 \\
\hline Microscopic & Yes & 15 & $18.0 \pm 8.04$ & 0.32 \\
\hline Invasion & No & $18.6 \pm 8.71$ & $22.0 \pm 4.04$ & \\
\hline
\end{tabular}

\# Calculation of $\mathrm{p}$ not possible due to little number of patients. 
the non-anatomical resection group with a positive surgical margin was extremely poor. When non-anatomic resection was selected, a surgical margin without tumor exposure may provide better survival.

A study by Yoshioka et al. ${ }^{38}$ predicted early recurrence in HCC after radical resection based on whole human gene expression profiling using microarray analyses. This study concluded that gene expression pattern related to early intrahepatic recurrence inherited in primary HCC can be used for the prediction of prognosis. Further studies based on genetic analysis may provide more evidence regarding the origins of recurrent tumors.

\section{Conclusion:}

We conducted this retrospective analysis for patients with HCC undergoing hepatic resection, and examined the background and clinical outcomes. The local recurrence rate was similar after anatomical and nonanatomical resection. Disease-free and overall survivals after anatomical and nonanatomical resection were not significantly different. Hepatic resection in cirrhotic patients should be done with good expertise and follows strict selection criteria. NonAnatomical resection may be more preferable in cirrhotic patients with small HCC to leave adequate functioning liver parenchyma and to avoid increased postoperative morbidity.

\section{Reference:}

1- Kamangar F, Dores GM, Anderson WF: Patterns of cancer incidence, mortality, and prevalence across five continents: Defining priorities to reduce cancer disparities in different geographic regions of the world. $J$ Clin Oncol 2006; 24: 2137-2150.

2- Parkin DM, Bray F, Ferlay J , Pisani P: Estimating the world cancer burden: Globocan 2000. Int $J$ Cancer 2001; 94: 153-156.

3- Fan ST, Lo CM, Liu CL, Lam CM, Yuen WK, Yeung C , Wong J: Hepatectomy for hepatocellular carcinoma: Toward zero hospital deaths. Ann Surg 1999; 229: 322-330.

4- Makuuchi M, Imamura H, Sugawara Y, Takayama T: Progress in surgical treatment of hepatocellular carcinoma. Oncology 2002; 62(Suppl 1): 74-81.

5- Yamanaka N, Okamoto E, Kawamura E, Kato T, Oriyama T, Fujimoto J, Furukawa K, Tanaka T, Tomoda F, Tanaka W: Dynamics of normal and injured human liver regeneration after hepatectomy as assessed on the basis of computed tomography and liver function. Hepatology 1993; 18: 79-85.

6- Takano S, Oishi H, Kono S, Kawakami S, Nakamura M, Kubota N, Iwai S: Retrospective analysis of type of hepatic resection for hepatocellular carcinoma. $\mathrm{Br} \mathrm{J}$ Surg 2000; 87: 65-70.

7- Tanaka K, Shimada H, Matsumoto C, Matsuo K, Nagano Y, Endo I, Togo S: Anatomic versus limited nonanatomic resection for solitary hepatocellular carcinoma. Surgery. 2008; 143: 607-615.

8- Torzilli G, Makuuchi M, Inoue K, Takayama T, Sakamoto Y, Sugawara Y, Kubota K, Zucchi A: No-mortality liver resection for hepatocellular carcinoma in cirrhotic and noncirrhotic patients: Is there a way? A prospective analysis of our approach. Arch Surg 1999; 134: 984-992.

9- Kondo K, Chijiiwa K, Makino I, Kai M, Maehara N, Ohuchida J, Naganuma S: Risk factors for early death after liver resection in patients with solitary hepatocellular carcinoma. J Hepatobiliary Pancreat Surg 2005; 12: 399-404.

10- Suh KS: Systematic hepatectomy for small hepatocellular carcinoma in Korea. $J$ Hepatobiliary Pancreat Surg 2005; 12: 365-370.

11- Kaibori M, Matsui Y, Hijikawa T, Uchida Y, Kwon AH , Kamiyama Y: Comparison of limited and anatomic hepatic resection for hepatocellular carcinoma with hepatitis C. Surgery 2006; 139: 385-394.

12- Poon RT, Fan ST, Lo CM, Ng IO, Liu CL, Lam CM, Wong J: Improving survival results after resection of hepatocellular carcinoma: A prospective study of 377 patients over 10 years. Ann Surg 2001; 234: 63-70.

13- Poon RT: Differentiating early, late recurrences after resection of $\mathrm{HCC}$ in cirrhotic patients: Implications on surveillance, prevention, and treatment strategies. Ann Surg Oncol 2009; 16: 792-794.

14- Thompson Coon J, Rogers G, Hewson P, Wright D, Anderson R, Cramp M, Jackson S, Ryder S, Price A, Stein K: Surveillance of cirrhosis for hepatocellular carcinoma: Systematic review and economic analysis. 
Health Technol Assess 2007; 11: 1-206.

15- Sherman M: Screening for hepatocellular carcinoma. Hepatol Res 2007; 37 (Suppl 2): 152-165.

16- Trevisani F, De NS, Rapaccini G, Farinati F, Benvegnu L, Zoli M, Grazi GL, Del PP, Di N, Bernardi M: Semiannual and annual surveillance of cirrhotic patients for hepatocellular carcinoma: Effects on cancer stage and patient survival (Italian experience). Am J Gastroenterol 2002; 97 : 734-744.

17- Llovet JM, Burroughs A , Bruix J: Hepatocellular carcinoma. Lancet 2003; 362: 1907-1917.

18- Takayama T, Makuuchi M, Hirohashi S, Sakamoto M, Yamamoto J, Shimada K, Kosuge T, Okada S, Takayasu K, Yamasaki S: Early hepatocellular carcinoma as an entity with a high rate of surgical cure. Hepatology 1998; 28: 1241-1246.

19- Grazi GL, Ercolani G, Pierangeli F, Del Gaudio M, Cescon M, Cavallari A, Mazziotti A: Improved results of liver resection for hepatocellular carcinoma on cirrhosis give the procedure added value. Ann Surg 2001; $234: 71-78$.

20- Poon RT, Fan ST, Lo CM, Liu CL, Wong J: Long-term survival and pattern of recurrence after resection of small hepatocellular carcinoma in patients with preserved liver function: Implications for a strategy of salvage transplantation. Ann Surg 2002; 235: 373-382.

21- Shah SA, Greig PD, Gallinger S, Cattral MS, Dixon E, Kim RD, Taylor BR, Grant DR, Vollmer CM: Factors associated with early recurrence after resection for hepatocellular carcinoma and outcomes. J Am Coll Surg 2006; 202: 275-283.

22- Poon RT, Fan ST, Ng IO, Lo CM, Liu CL, Wong J: Different risk factors and prognosis for early and late intrahepatic recurrence after resection of hepatocellular carcinoma. Cancer 2000; 89: 500-507.

23- Imamura H, Matsuyama Y, Tanaka E, Ohkubo T, Hasegawa K, Miyagawa S, Sugawara Y, Minagawa M, Takayama T, Kawasaki S, Makuuchi M: Risk factors contributing to early and late phase intrahepatic recurrence of hepatocellular carcinoma after hepatectomy. J Hepatol 2003; 38: 200-207.

24- Portolani N, Coniglio A, Ghidoni S, Giovanelli M, Benetti A, Tiberio GA, Giulini SM: Early and late recurrence after liver resection for hepatocellular carcinoma:
Prognostic and therapeutic implications. Ann Surg 2006; 243: 229-235.

25- Cucchetti A, Piscaglia F, Caturelli E, Benvegnu L, Vivarelli M, Ercolani G, Cescon M, Ravaioli M, Grazi GL, Bolondi L, Pinna AD: Comparison of recurrence of hepatocellular carcinoma after resection in patients with cirrhosis to its occurrence in a surveilled cirrhotic population. Ann Surg Oncol 2009; 16: 413-422.

26- Regimbeau JM, Kianmanesh R, Farges O, Dondero F, Sauvanet A, Belghiti J: Extent of liver resection influences the outcome in patients with cirrhosis and small hepatocellular carcinoma. Surgery 2002; 131: 311-317.

27- Emond JC, Polastri R: Anatomical hepatectomy for resection or transplantation. Am J Surg 1996; 172: 29-34.

28- Mazziotti IA, Grazi GL, Ercolani G: Hepatic resective surgery in cirrhotic patients. Techniques and results of anatomical segmentectomies. Ann Ital Chir 1997; 68: 781-790.

29- Takayama T, Makuuchi M, Yamasaki S, Kosuge T, Yamamoto J, Shimada K: Systematic resection for hepatocellular carcinoma. Jpn Surg Soc 1998; 99 : 241-244.

30- Imamura H, Matsuyama Y, Miyagawa Y: Prognostic significance of anatomical resection and des-gamma-carboxy prothrombin in patients with hepatocellular carcinoma. Br J Surg 1999; 86: 1032-1038.

31- Regimbeau JM, Kianmanesh R, Farges O, Dondero F, Sauvanet A, Belghiti J: Extent of liver resection influences the outcome in patients with cirrhosis and small hepatocellular carci-noma. Surgery 2002; 131: 311-317.

32- Ziparo V, Balducci G, Lucandri G, Mercantini P, Giacomo G, Fernandes E: Indications and results of resection for hepato-cellular carcinoma. Eur J Surg Oncol 2002; 28: $723-728$.

33- Imamura H, Matsuyama Y, Tanaka E: Risk factors contributing to early and late phase intrahepatic recurrence of hepatocellular carcinoma after hepatectomy. J Hepatol 2003; 38: 237-239.

34- Shirabe K, Kanematsu $T$, Matsumata $T$, Adachi E, Akazawa K, Sugimachi K: Factors linked to early recurrence of small hepatocellular carcinoma after hepatectomy: Univariate and multivariate analyses. Hepatology 1991; 14: 802-805.

35- Scheele J: Anatomical, atypical liver 
resections: Chirurg 2001; 72: 113-124.

36- Kanematsu T, Takenaka K, Matsumata $T$, Furuta T, Sugimachi K, Inokuchi K: Limited hepatic resection effective for selected cirrhotic patients with primary liver cancer. Ann Surg 1984; 199: 51-56.

37- Nanashima A, Sumida Y, Abo T, Nagasaki T, Tobinaga S, Fukuoka H, Takeshita H, Hidaka S, Tanaka K, Sawai T, Yasutake T, Nagayasu $\mathrm{T}$ : Comparison of survival between anatomic and non-anatomic liver resection in patients with hepatocellular carcinoma: Significance of surgical margin in non-anatomic resection. Acta Chir Belg 2008; 108(5): 532-537.

38- Yoshioka S, Takemasa I, Nagano H, Kittaka N, Noda T, Wada H, Kobayashi S, Marubashi S, Takeda Y, Umeshita K, Dono K, Matsubara $\mathrm{K}$, Monden M: Molecular prediction of early recurrence after resection of hepatocellular carcinoma. Eur J Cancer 2009; 45: 881-889. 


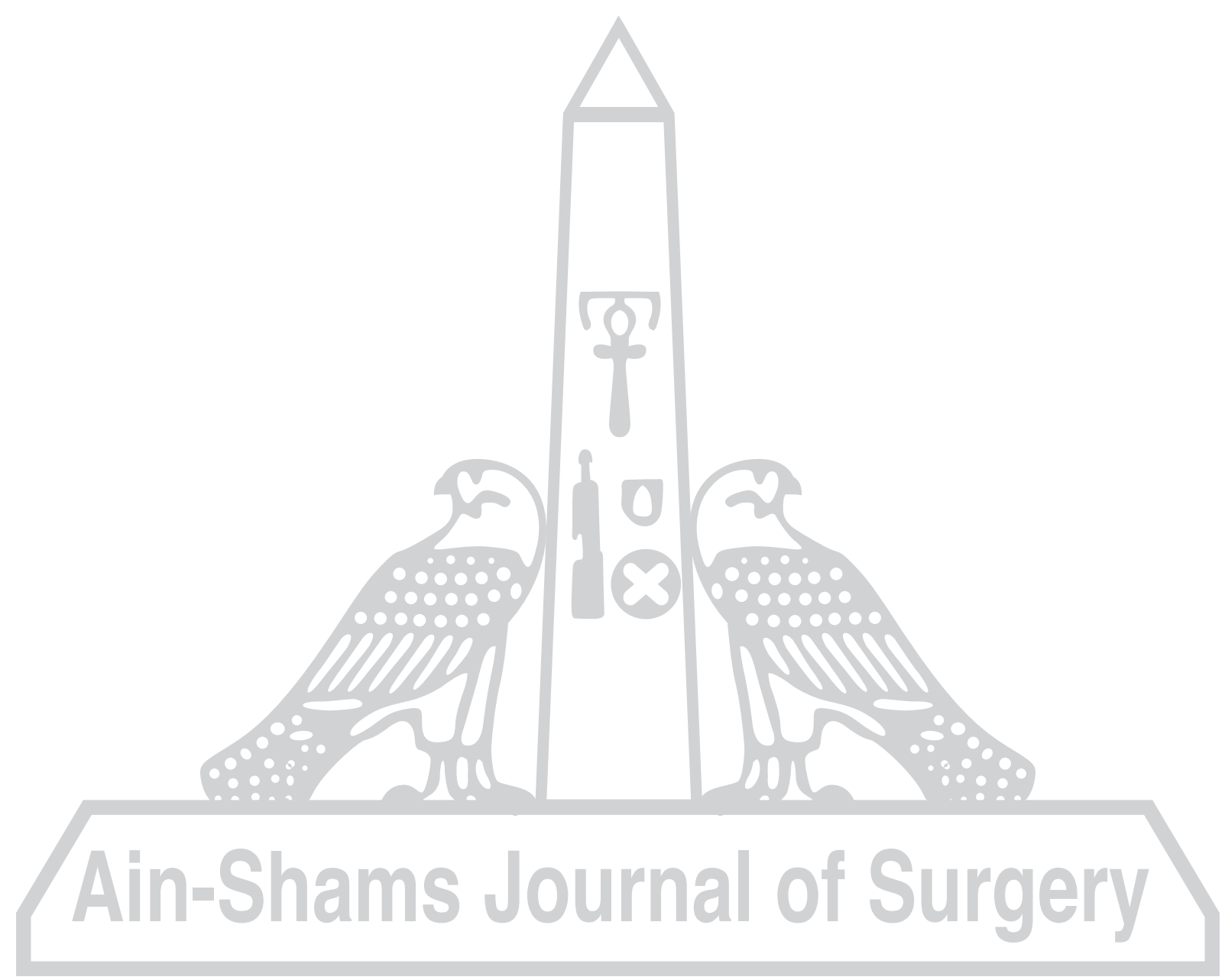

